\title{
Spatial distribution of cyanobacteria and algae from the tombstone in a historic cemetery in Bratislava, Slovakia
}

\author{
Bohuslav UHER \\ Department of Botany and Zoology, Faculty of Science, Masaryk University in Brno, Kotlářská 2, 61137 Brno, \\ Czech Republic; e-mail: uherius@sci.muni.cz
}

\begin{abstract}
This study focuses on species composition and spatial distribution of cyanobacterial and algal communities colonizing the surface of the tombstone. Ecological and taxonomical data were used for evaluation of changes in their vertical distribution. A total of 25 taxa were identified, 13 of them belonging to chlorophytes, 12 to other groups of algae and cyanobacteria; in addition four mosses and one liverwort occurred at 17 sampling sites. Three species, Klebsormidium crenulatum, Desmococcus olivaceus and Stichococcus bacillaris, were found as the most abundant taxa. The aeroplanctonic species Desmococcus olivaceus, Stichococcus bacillaris and Klebsormidium crenulatum were detected from the air-fall. Investigated microhabitats offer relatively stabile microclimatic conditions and, likely, they are responsible for the observed vertical distribution of cyanobacteria and algae. Humidity was the main microclimatic factor influencing diversity, distribution and abundance of algae on investigated terrestrial substrate.
\end{abstract}

Key words: cyanobacteria, algae, urban habitats, biodeterioration, stone, Bratislava, Slovakia

\section{Introduction}

Paraphrasing a classic definition of soil (KRUMBEIN et al. 1992), stone monuments may be defined as the place where art and (micro)biology encounter each other. The biodeterioration of stones is a phenomenon that has gained wide interest (UrZI \& KRUMBeIN 1994). Surfaces of minerals provide substrate for a large group of different microorganisms (KRUMBEIN \& URZI 1992). On stone monuments, most organisms occur on the surface and their growth results in formation of more or less thick biofilms that originate from the air-borne cells and spores. The presence of different species on substrates, which have been thus transformed, is indicative of the undergoing biodeterioration processes (URZI \& KRUMBEIN 1994). Therefore, the knowledge of the biology of lithobionts is the basis for understanding the adaptation of microorganisms to such extreme environments, and it allows us to predict the potential biodeterioration risks in the substrate. Within microbial communities, algae and cyanobacteria are primary producers due to their phototrophic nutrition and low nutrient requirements. They grow on cornices, in holes and fissures or beneath crusts, where water is retained, and often form rather apparent green biofilms (Golubić et al. 1981, JohANSEN et al. 1983, Characklis 1984, John 1988, Albertano \& Grilli Caiola 1989, Danin \& Caneva 1990, Pentecost 1992, Ariño et al. 1997, Asencio \& Aboal 2000, Lamenti et al. 2000, Albertano \& Bellezza 2001, Godyová et al. 2003, Rindi \& GUIRY 2003, Uher et al. 2005).

This study reports the most common species of cyanobacteria and algae growing on the surface of a tombstone and tomb covers dating from 1956 at the historic cemetery of Pressburg Evangelicals „Kozia brána“ in the centre of Bratislava city. The ecological and taxonomic data were used for evaluation of changes in the vertical distribution of individual species.

\section{Materials and methods}

Samples were collected monthly in 2002 on the transect from the top part of the sculpture to the bottom part (near the soil surface) of the gravestones allowing the detailed study of the vertical distribution of algal assemblages on this man-made monument ("Mother with two daughters") (Figs 24-27). The sampling 
sites were shaded by trees and protected against wind by cementery walls; relative humidity was high (8098\%) measured (1 meter above the soil surface) using a thermo-hygrometer (Mütec Instruments $\mathrm{GmbH}$, Germany) and wind turbulences were not observed. Six vertical zones from the top to the base were distinquised (A-E on sculpture; F on tomb covers) (Figs 24-27). Samples from 17 permanent sites were studied in both natural and cultured material using LM (Olympus BX 50). The scrapped samples were aseptically inoculated on agar or to liquid medium in tubes and Petri dishes. The following culture media were used: BG11 (RIPPKA et al. 1979), BG11 (RIPPKA 1988) and BBM (SMITH \& Bold 1966). Unialgal strains were used for a detailed study of morphological variation, reproduction and ontogenesis to confirm identification of species. For the capturing of aeroplanktonic species, agarized slides placed on the sampling sites were used.

Cyanobacteria and algae were identified according to the following literature: GEITLER (1932), Desikachary (1959), Groover \& Bold (1969), Ettl (1978), Komárek \& Fott (1983), Hoffmann (1986), HindÁK (1990), LOKHORST (1992, 1996), EtTL \& GÄRTNER (1995), KomÁrek \& ANAgnostidis (1998, 2005).

\section{Results}

In total, 25 subaerial algae were identified: eight species of Cyanobacteria, four species of Heterokontophyta and 13 Chlorophyta (see Table 1). They were found on 17 sampling places. Three species, Klebsormidium crenulatum,Desmococcus olivaceus and Stichococcus bacillaris, represented more abundant taxa than other representatives associated with specific microenvironments. Only three aeroplanktonic species including Desmococcus olivaceus, Stichococcus bacillaris and Klebsormidium crenulatum were captured using agarized slides.

Six vertical zones (A, B, C, D, E and F zone; Fig. 24-27) were a priori delimited. In general, the algal species richness was the lowest on the top of sculpture (zones A-C, 6 species, see Table 1) and the highest on the bottom (16 species in zone F, Table 1, Figs 24-27). Zones exposed to desiccation (A-C and E) were dominated by green algae Chlorella kessleri, Desmococcus olivaceus and Klebsromidium crenulatum or $K$. flaccidum, which were accompanied by Stichococcus bacillaris, Coccomyxa confluens and Trebouxia arboricola. However, in zone $\mathrm{D}$ with higher relative air humidity, the species richness was two times higher (13 taxa). Some species were widespread and they occupied a large range of microhabitats. The bottom zones (F), covered by mosses, were more favourable for algal growth due to their protection against desiccation by wind. Bryophytes and liverworts such as Rhynchostegium murale (HEDw.) BRUCH et SchIMP. in BSG, Eurynchium hians (HEDw.) SANDE Lac. and Lunularia cruciata (L.) DumorT. ex LINDB. offered varied mosaic of microhabitats for algal colonization. In assemblages associated with mosses, the cyanobacterium Leptolyngbya fragilis and alga Cosmarium parvulum var. undulatum were identified. This desmid is mostly incorrectly identified as Actinotaenium (Nägeli) TEILING species and has not been recorded from hemiatmophytic environments (Frans Kouwets, pers. comm.). Within assemblages from sites without mosses (site 17), mainly cyanobacteria adapted to desiccation due to presence of mucilagenous sheaths were found.

Some interesting and unknown species or species with unclear taxonomy, such as Heteroleibleinia pusilla, Heterococcus sp., Theleasphaera alpina and Trebouxia arboricola, were found during the study.

Heteroleibleinia pusilla (HANSG.) COMPÈRE (Fig. 3) Although $H$. pusilla was previously recorded from swamps and ponds with submerged vegetation (KomÁREK \& ANAGNOSTIDIS 2005), narrow filaments (1.5 $\mu \mathrm{m}$ wide) were found growing aerophytically on mosses. Filaments of this species were attached by one end to the substrate during the entire life cycle. This feature could easily be overlooked, therefore similar specimens were previously incorrectly identified as other subaerial cyanobacteria, such as Leptolyngbya (investigated mostly in cultures). The genus Heteroleibleinia (GeITLER) L. HofFMANN was mostly classified as a section of Lyngbya.

\section{Heterococcus sp.}

(Fig. 22)

Mature representatives were stellate, separate, composed of an extensive caespitose system, radially arranged, ramified, prostrate branches projecting from a small compact central disc. Plants were not easily disintegrating; branched, primary filaments were open and often tenuous. Zoosporogenesis or aplanosporogenesis was not observed. Cell length ranged from 4 to 25; cell width ranged from (3) 4 to $5(6) \mu \mathrm{m}$. The above mentioned data confirmed the variability of morphometric characters of this species 

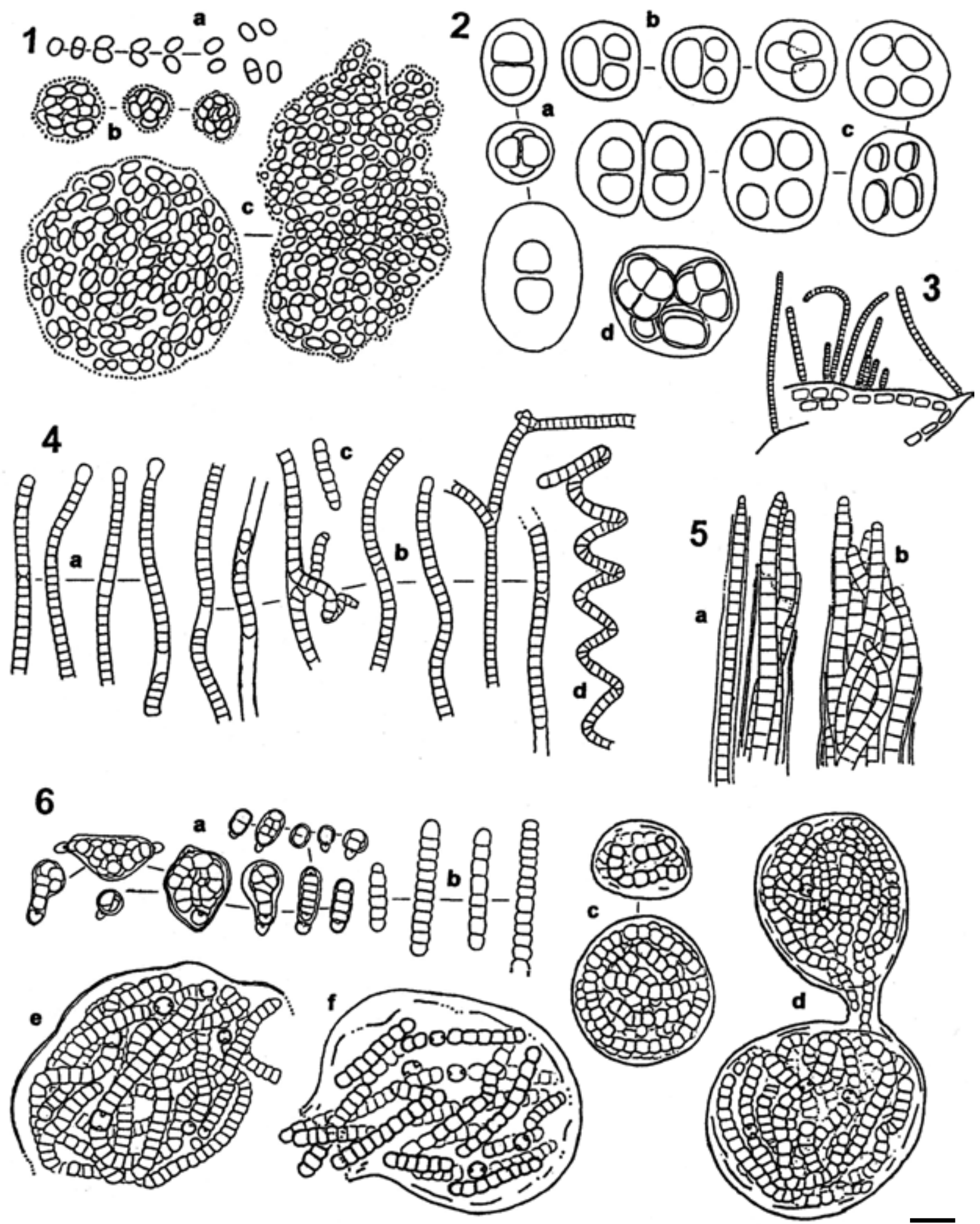

Figs 1-6. Cyanobacteria/cyanophytes: (1) Aphanothece stagnina [(a) initial stages, (b) young colonies, (c) adult colonies]; (2) Chroococcus varius [(a) initial stages, (b) three-celled stages, (c) young colonies, (d) adult colony]; (3) Heteroleibleinia pusilla: trichomes attached on the surface of moss leaves; (4) Leptolyngbya fragilis [(a) filaments with rounded or globular apical cells, (b) false branching filaments, (c) hormogonium, (e) twisted filament]; (5) Microcoleus vaginatus [(a) young colony, (b) colony of trichomes in common sheats]; (6) Nostoc microscopicum [(a) initial stages with heterocyte, (b) hormogonia, (c) young subspherical colonies, (d, e) adult colony, (f) ruptured old colony]. Scale bar $10 \mu \mathrm{m}$. 

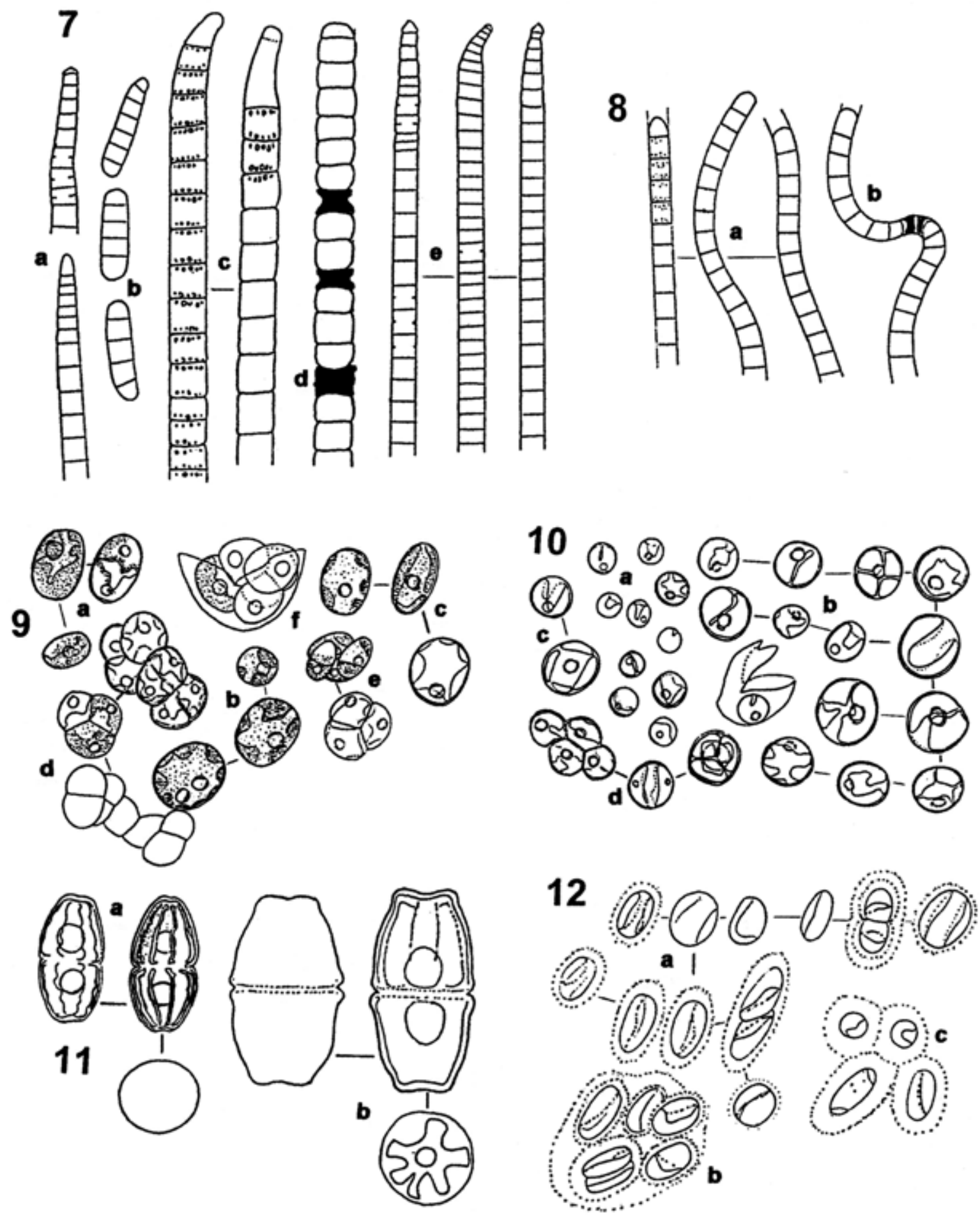

Figs 7-8. Cyanobacteria/cyanophytes: (7) Phormidium autumnale [(a) apical parts of trichomes, (b) hormogonia, (c, e) trichomes, (d) fragmentation by necridic cells]; (8) Phormidium corium [(a) filaments, (b) fragmentation by necridic cells]; Figs. 9-12. Chlorophytes: (9) Chlorella fusca [(a-c) young and adult cells, (d) colonies, (e) autospores, (f) ruptured autosporangium]; (10) Chlorella kessleri [(a) autospores, (b, c) adult cells, (d) autosporangia]; (11) Cosmarium parvulum var. undulatum [(a) small sized cells, (b) big sized cells]; (12) Coccomyxa confluens [(a) initial stages, (b, c) colonies]. Scale bar $10 \mu \mathrm{m}$. 


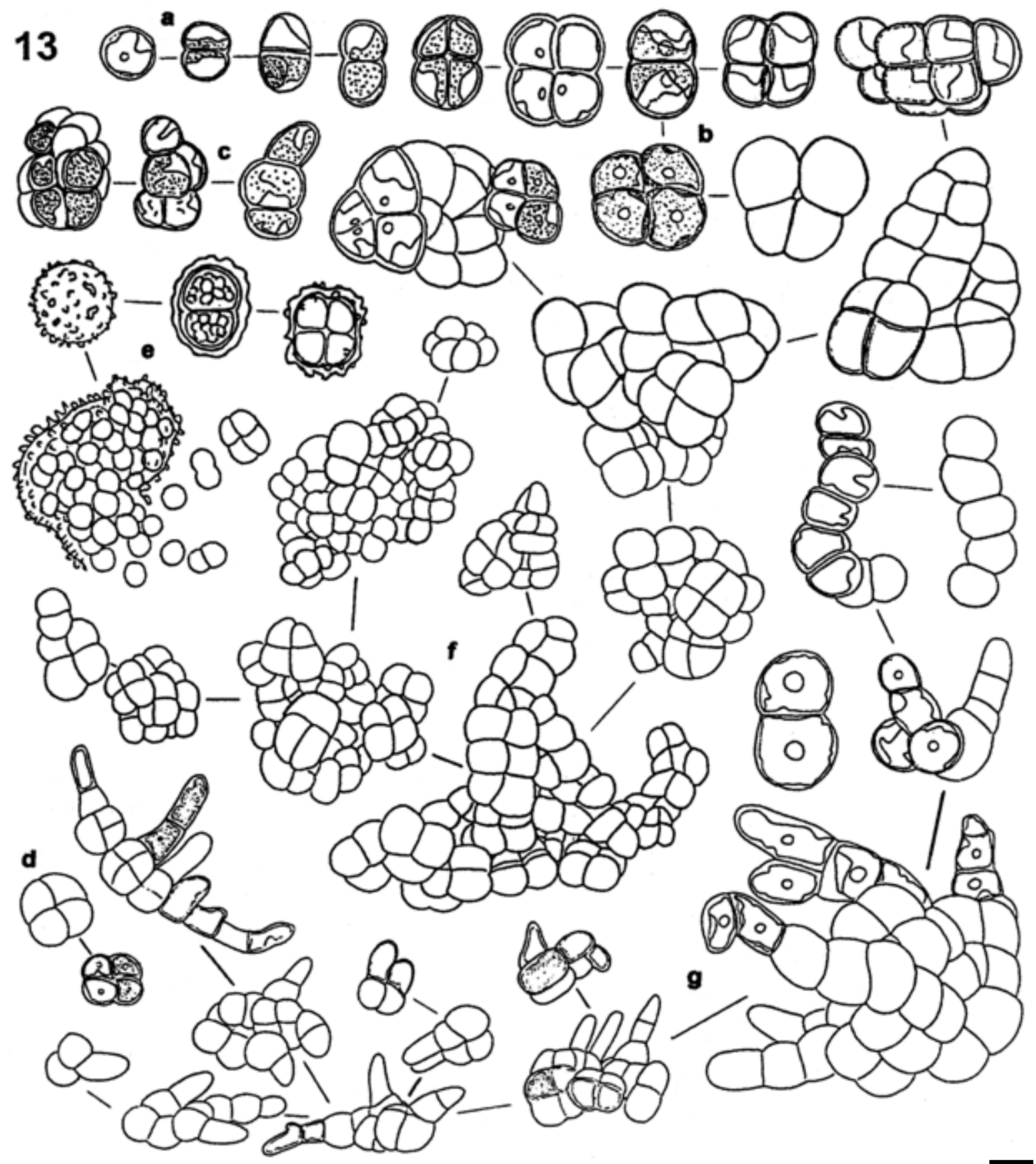

Fig.13. Desmococcus olivaceus: (a) initial stages; (b, c, d) four-celled colonies; (e) autosporangia; (f) packet like colonies; (g) pseudofilaments. Scale bar $10 \mu \mathrm{m}$.

depending on the character of media used. The genus Heterococcus is typical of terrestrial habitats and was partially revised by LOKHORST (1992), who used the methodology of cultivation on agar plates (BBM sensu Bold \& WynNE, 1978) for the taxonomic revision of this genus. The branch-forming and the colonies of genus Heterococcus ChоDAт are similar to green alga Pseudendoclonium (John \& Johnson 1989). From the algal group of Xanthophyceae, biodeteriogens are mentioned mainly in the genera of Heterothrix (Xanthonema), Botrydiopsis, Monodus and Chloridella (Ortega-CAlvo et al. 1993, Kapusta \& KovÁČIK 2000).

Thelesphaera alpina $\mathrm{PASCH}$.

(Fig. 20)

Cells were solitary, or in short pseudofilaments (3-7 cells), spherical, subglobular, with parietal 


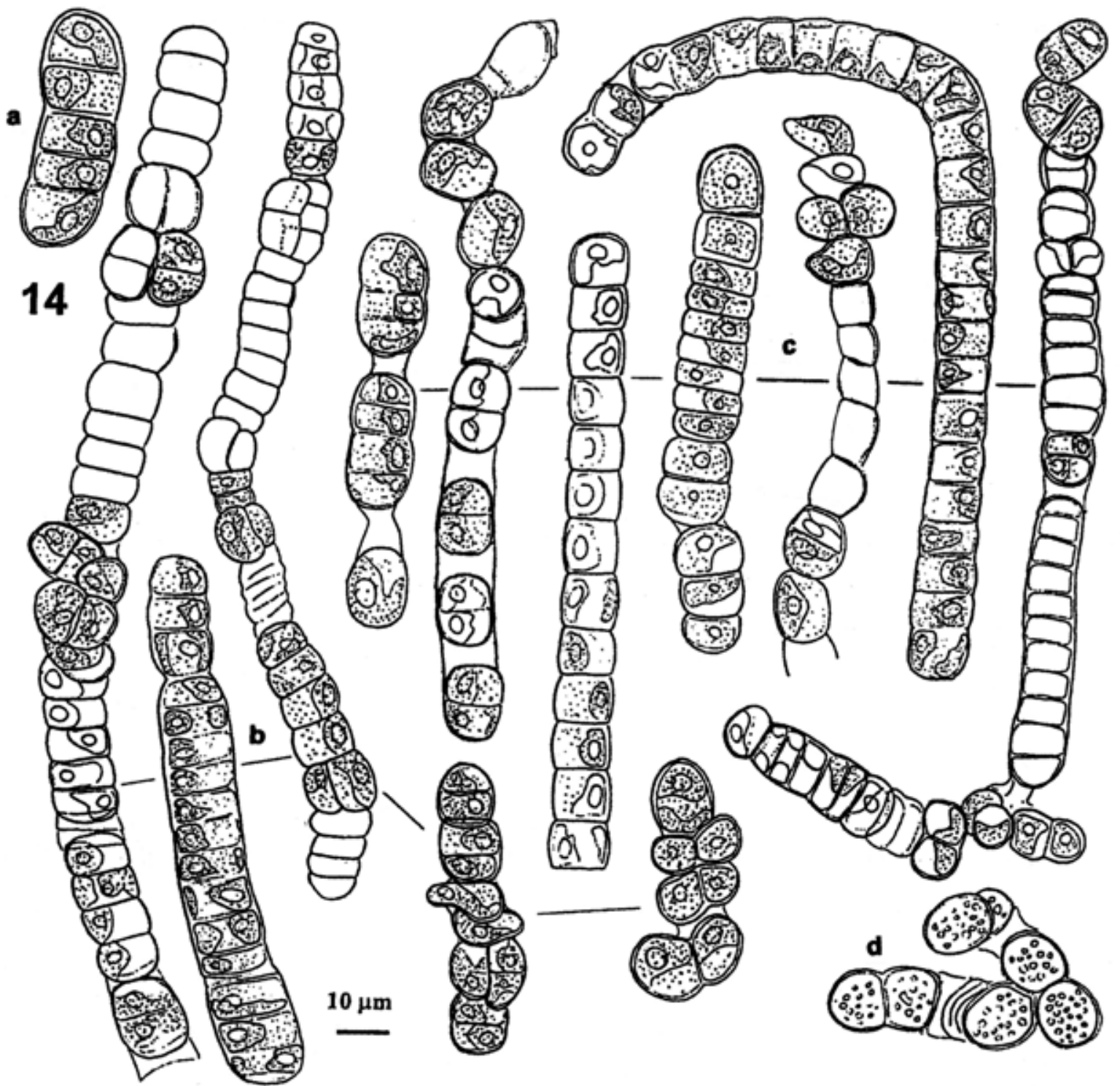

Fig.14. Klebsormidium crenulatum: (a) initial stage; (b, c) filaments with autosporangia; (d) old fragments of filaments. Scale bar $10 \mu \mathrm{m}$.

slightly lobed chloroplasts occupying more than half of the cell wall. Cell wall was structured with conical and thick protuberances. Cells had 10.5$12.5 \mu \mathrm{m}$ in diameter. The genus Thelesphaera was described by PAScher (1939). This mentioned species is easily mistaken for spores of liverwort species and is not very commonly known from hemi-atmophytic environments.

Trebouxia arboricola PUYM.

(Fig. 21)

Cells were solitary, or in small groups $2(-4)$, spherical, sometimes ovoidic, with massive lobed central chloroplasts and 1-2 pyrenoids; cells had $15-20 \mu \mathrm{m}$ in diameter, cell wall was thin $(0.3-1.2 \mu \mathrm{m})$; zoospores not observed. Trebouxia arboricola is an epiphytic or epilithic species, known from stone monuments (WASSER et al. 1988, Kapusta \& KovÁčí 2000). T. decolorans AhMADJIAN was reported by Ortega-CALVo et al. $(1991,1993)$ as a biodeteriogen of monuments in Spain and Italy; T. arboricola was reported by RINDI \& GUIRY (2003) from Galway City (Ireland). T. schowmanii HILDRET et AHMADJIAN was mentioned from monuments in Olivia (Ukraine) by Darienko \& HofFMAnN (2003). These species are the typical subaerial species mentioned mainly as the phycobionts of lichens (ETTL \& GÄRTNER 1995). 


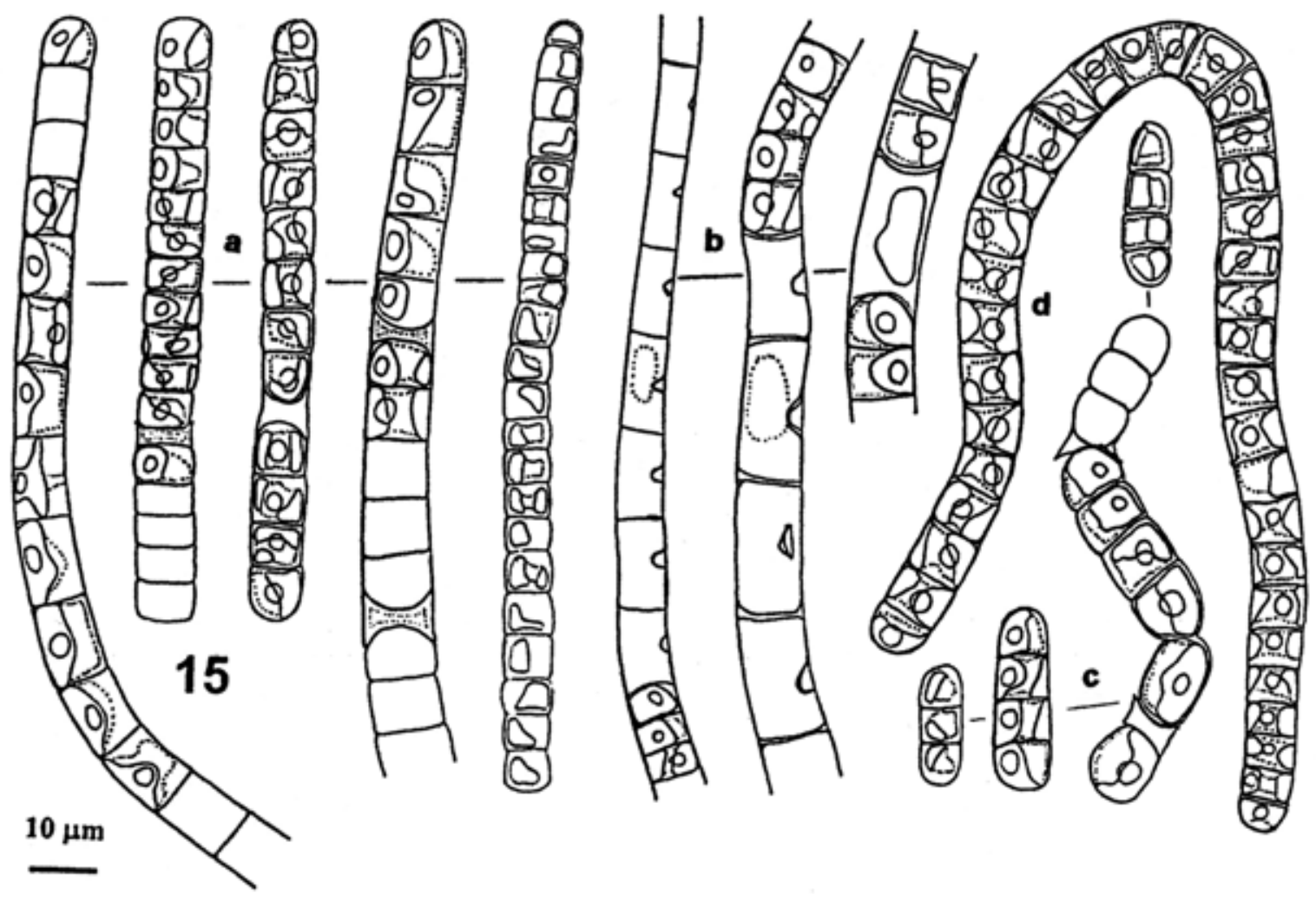

Fig.15. Klebsormidium flaccidum: (a, d) sterile filaments; (b) filaments with empty zoosporangia; (c) fragments of filaments. Scale bar $10 \mu \mathrm{m}$.

\section{Discussion}

High variation in abundance and distribution of cyanobacteria and algae on very small spatial scale of a single monument was found. The algal species richness increased in direction from top to the bottom part of the sculpture. This distribution pattern, recorded also by other authors (NOGUEROLSeOane \& Rifón-Lastra 1997, Rifón-Lastra \& Noguerol-SeoAne 2001, Uher et AL. 2005), was influenced by humidity, exposition to desiccation and surface characteristics. Cyanobacteria and algae inhabited a large range of microhabitats from dry stone surface on the top to wet bryophyte cover on the sculpture bottom. Although some authors discussed seasonal variation of subaerial assemblages (RIFón-LASTRA \& NOGUEROL-SEOANE 2001), my results illustrate that the position of the sampling site on the monument was more important than the time of year when samples were taken (cf Tables 1 and 2). Differences in species richness during season were negligible with the only exception of zone F (Table 2). Most of the identified subaerial algae belong to widespread genera (Klebsormidium, Desmococcus) but some of them are very rare and considered to inhabit specific microenvironments in association with mosses (Cosmarium parvulum var. undulatum, Heteroleibleinia pusilla.). The artificial urban habitats are more likely to be colonized by species and spores transported mostly by air (aeroplankton) in the upper zones A-D and by soil algae in the bottom zones E-F. Particularly chlorophytes captured on exposed agarized slides as aeroplankton (Desmococcus olivaceus, Stichococcus bacillaris and Klebsormidium crenulatum) originated possibly from surrounding natural terrestrial habitats. For example, Desmococcus olivaceus has mostly been recorded from bark or soil algal communities (GÄRTNER \& InGOLIĆ 2003, RINDI \& GUIRY 2003). As an example of different autecology the representatives of the genus Klebsormidium (K. crenulatum and $K$. flaccidum) may be used. Klebsormidium flaccidum, a well-known and widespread soil alga, was frequently found in the bottom part (zone E); on the other hand $K$. crenulatum transported as aeroplankton was frequent in the upper zones. 


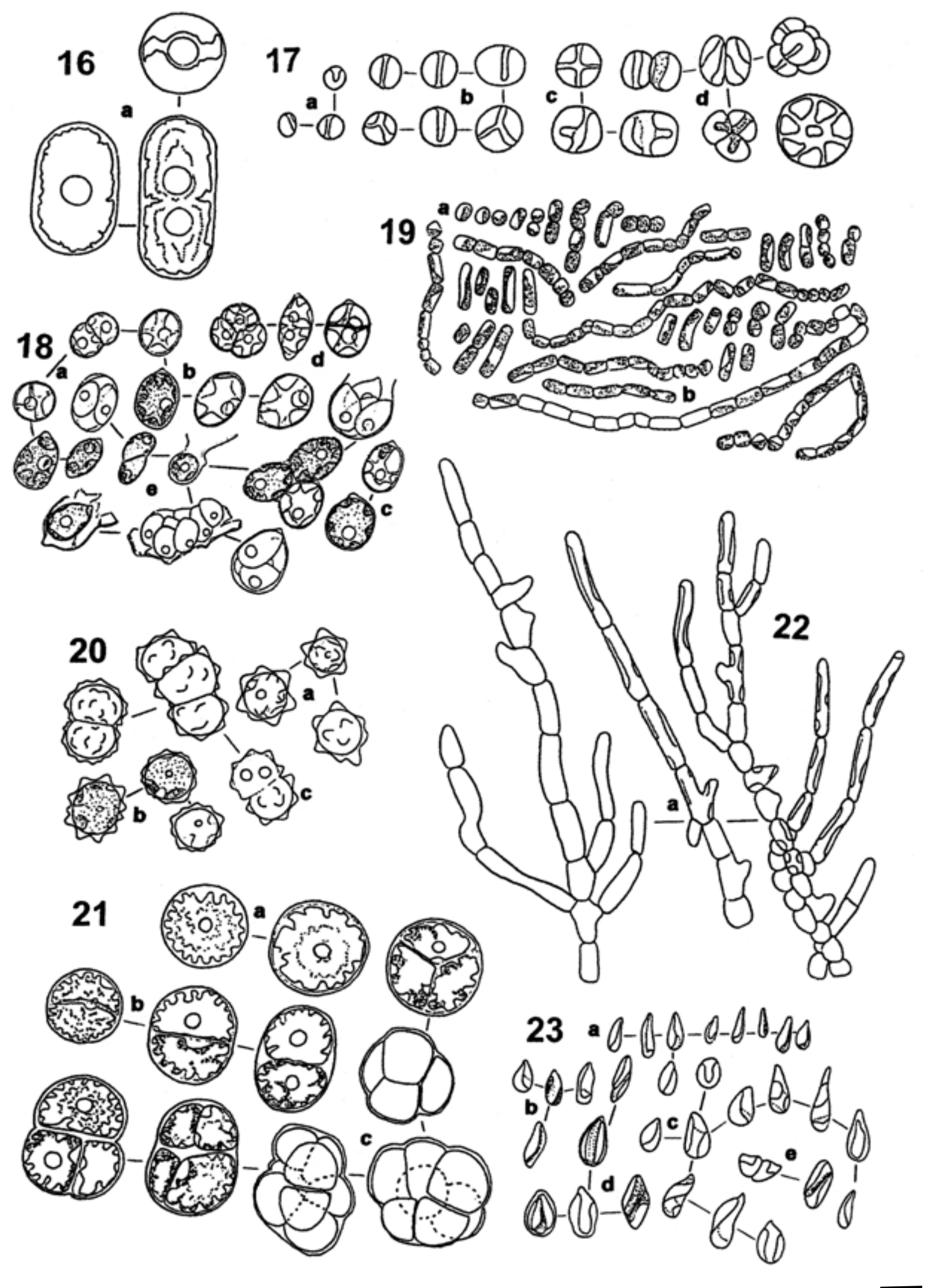

Figs 16-21. Chlorophytes: (16) Mesotaenium macrococcum [(a) types of cell shape with one chloroplast]; (17) Muriella terrestris [(a) initial stages, (b) young cells, (c, d) autosporangia]; (18) Oocystis asymetrica [(a, b, c) initial stages and young cells, (d) cell division, (e) autosporangia]; (19) Stichococcus bacillaris [(a) initial stages, (b) pseudofilaments]; (20) Theleasphaera alpina [(a) unicelled stages with protuberances of cellwall, (b) cell division]; (21) Trebouxia arboricola [(a) initial stages, (b) cell division, (c) colonies]; Figs 22-23. Heterokontophyta: (22) Heterococcus sp. [(a) branches of adult colony]; (23) Monodus unipapilla [(a) autospores, (b, c) young cells, (d, e) autosporangia]. Scale bar $10 \mu \mathrm{m}$. 


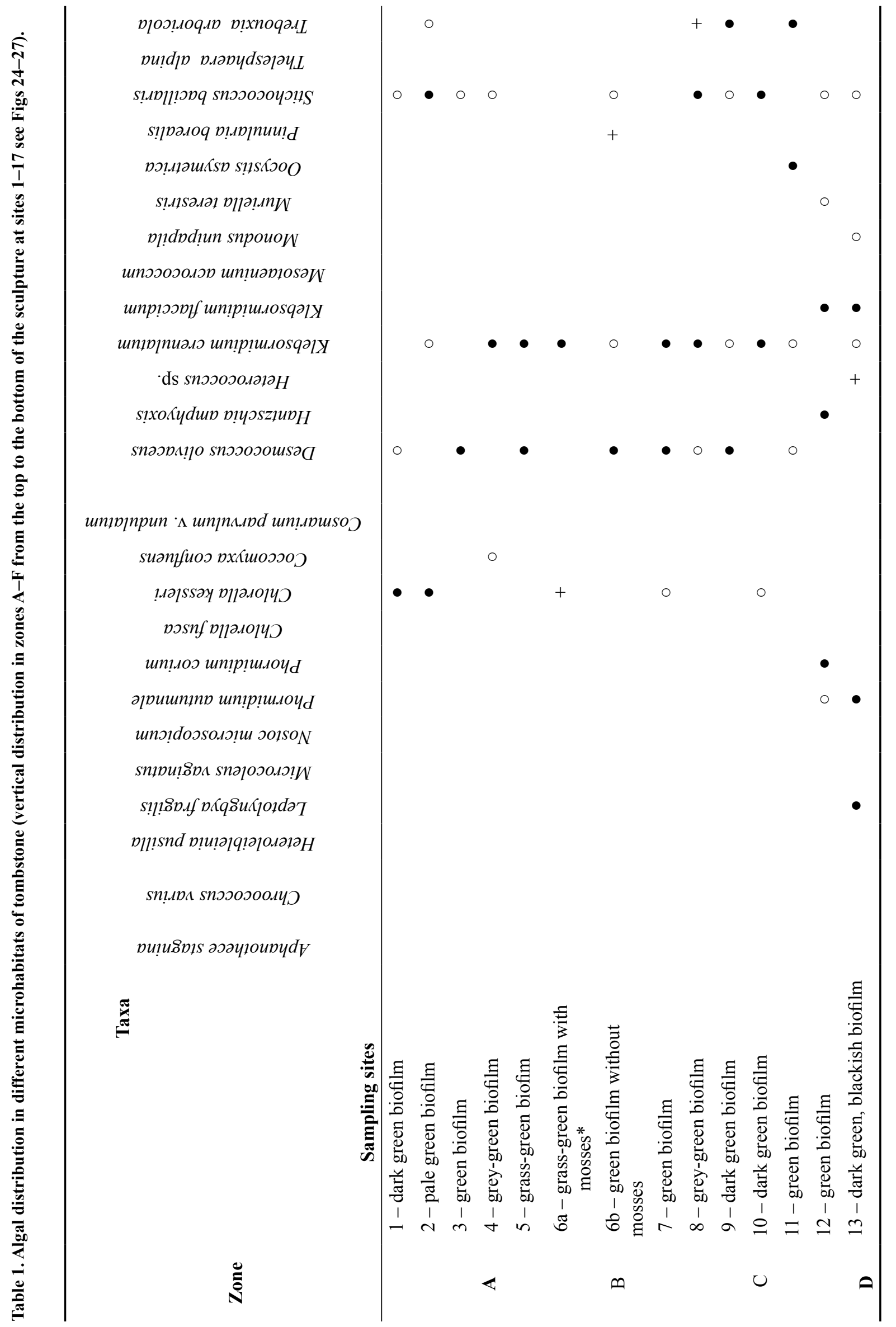




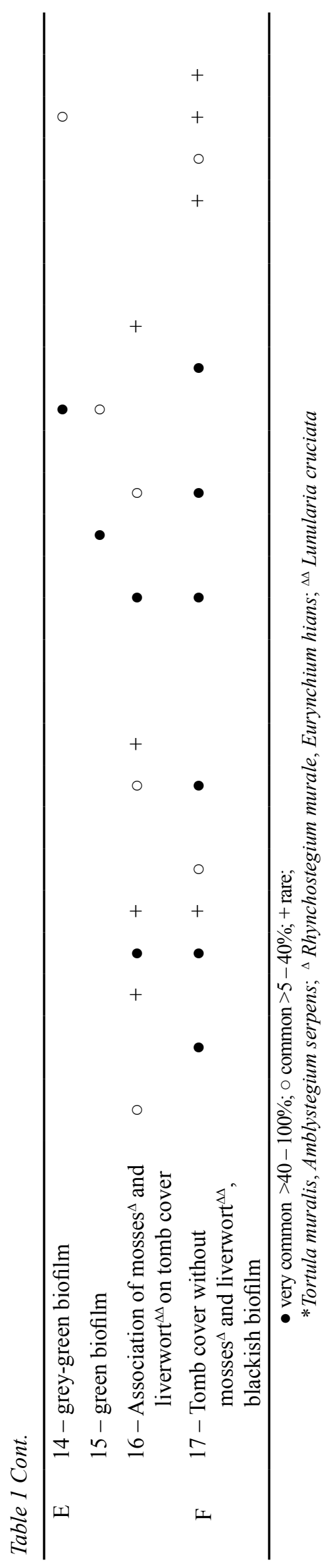

\section{Acknowledgements}

Financial support for this study was provided by the Funding of the Ministry of Education of the Czech Republic; project No. MSM0021622416. I would like to thank Dr. Frans Kouwets and Prof. Peter Coesel (University of Amsterdam) who helped in the identification of desmids, Dr. J. R. Johansen (John Carroll University) who kindly revised the English style of the submitted version of the manuscript and two anonymous reviewers whose corrections were followed in the final version. I would like to express my gratitude to RNDr. L'ubomír Kováčik, CSc. for his invitation to access his collection of literature.

\section{References}

Albertano, P. \& Bellezza, S. (2001): Cytochemistry of cyanobacterial exopolymers in biofilms from Roman hypogea. - Nova Hedwigia 123: 501518.

Albertano, P. \& Grilli Caiola, M. (1989):A hypogean algal association. - Braun-Blanquetia 3: 287292.

Ariño, X., Hernandez-Mariné, M. \& Saiz-Jimenez, C. (1997): Colonization of roman tombs by calcifing cyanobacteria. - Phycologia 36: 366373.

Asencio, A.D. \& Aboal, M. (2000): A contribution to knowledge of chasmoendolithic algae in cavelike environments. - Algological Studies 98: 133-151.

Characklis, W.G. (1984): Biofilm develo-pment: a process analysis. - In: MARSHALL, K.C. (ed.): Microbial Adhesion and Aggregation. - pp. 137-157, Springer Verlag, Berlin.

DANin, A. \& CANEva G. (1990): Deterioration of limestone walls in Jerusalem and marble monuments in Rome caused by cyanobacteria and cyanophilous lichens. - Intern. Biodeter. Biodegrad. 26: 397-417.

Darienko, T. \& Hoffmann, L. (2003): Algal growth on cultural monuments in Ukraine. - Biologia 58: 575-587.

Desikachary, T.V. (1959): Cyanophyta. - 686 pp., Indian Council for Agricultural Research, New Delhi.

EтtL, H. (1978): Xanthophyceae. - In: EтtL, H., Gerloff, J. \& Heynig, H. (eds): Süsswasserflora von Mitteleuropa. Vol. 3. - 549 pp., Gustav Fischer Verlag, Jena.

Ettl, H. \& GÄrTner, G. (1995): Syllabus der Boden-, Luft- und Flechtenalgen. - 436 pp., Gustav Fischer Verlag, Stuttgart, Jena, New York.

Gärtner, G. \& IngOlić E. (2003): Further studies on Desmococcus Brand emend. Vischer (Chlorophyta, Trebouxiophyceae) and a new species Desmococcus spinocystis sp. nov. from 
Table 2: Seasonal variation of species richness on tombstone (zones A-F see Figs 24-27).

\begin{tabular}{lcccccccccccc}
\hline & & & \multicolumn{1}{c}{ Month } & & & \\
Zones & I & II & III & IV & V & VI & VII & VIII & IX & X & XI & XII \\
\hline A & 6 & 6 & 6 & 6 & 6 & 6 & 6 & 6 & 6 & 6 & 6 & 6 \\
B & 5 & 5 & 6 & 6 & 6 & 6 & 6 & 6 & 6 & 6 & 6 & 6 \\
C & 6 & 6 & 6 & 6 & 6 & 6 & 6 & 6 & 6 & 6 & 6 & 6 \\
D & 9 & 9 & 9 & 10 & 10 & 10 & 10 & 10 & 10 & 10 & 10 & 10 \\
E & 3 & 3 & 3 & 3 & 3 & 3 & 3 & 3 & 3 & 3 & 3 & 3 \\
F & 12 & 12 & 12 & 14 & 16 & 16 & 16 & 16 & 16 & 16 & 12 & 12 \\
\hline
\end{tabular}
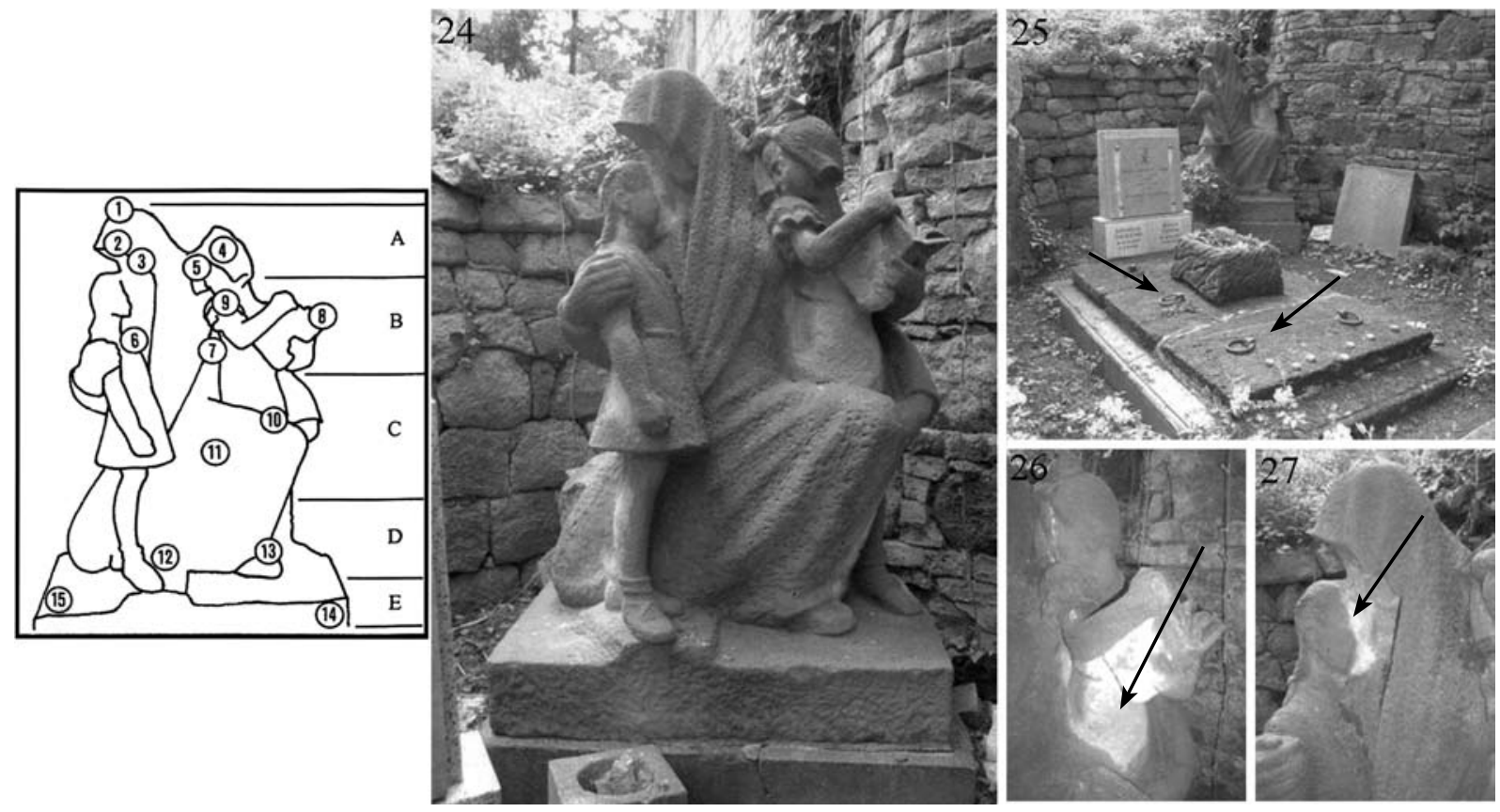

Figs 24-27. Tombstone (statue represent mother with two daughters) and tomb cover in the historic cemetery of Pressburg Evangelicals Kozia brána in the centre of Bratislava: (24) sampling places of algae (1-14) in different microhabitat zones (A-E); (25) tomb cover (zone F) with growths of liverworts and mosses (arrows); (26-27) detail views on weathered parts of statue (arrows).

soil. - Biologia 58: 517-523.

GeItLeR, L. (1932): Cyanophyceae. - In: RABENHORST, L. (ed.): Kryptogamen Flora 14. - 1196 pp., Aka-demische Verlags-Gesellschaft, Leipzig.

Godyová, M., UHER, B., ŠIMONovičová, A. \& ŠEvc, J. (2003): Mikrobiálna biodeteriorácia kameňa. Bull. Českoslov. Spol. Mikrobiol. 2: 37-48.

Golubić, S., Friedmann, I. \& Schneider, J. (1981): The lithobiontic ecological niche, with special reference to microorganisms. - J. Sediment. Petrol. 51: 475-478.

Groover, R.D. \& Bold, H.C. (1969): Phycological Studies VIII. The taxonomy and comparative physiology of the Chlorosarcinales and certain other edaphic algae. - The Univ. Texas Publ. 6907: 1-165.
HINDÁK, F. (1990): Studies on the chlorococcal algae (Chlorophyceae). V. - 192 pp., Veda, Bratislava.

Hoffmann, L. (1986): Cyanophycées aériennes et subaériennes du Grand-Duché de Luxembourg. - Bull. Jard. Bot. Nat. Belg. 56: 77-127.

Johansen, J.R., Rushforth, R.S., Orbendorfer, R., FungladDA, N. \& Grimes, J.A. (1983): The algal flora of selected wet walls in Zion National Park, Utah, USA. - Nova Hedwigia 38: 765-808.

JoHN, D.M. (1988): Algal growths on buildings: a general review and methods of treatment. Biodeterior. Abstracts 2: 81-102.

John，D.M. \& Johnson，L.R. (1989): A cultural assessment of the freshwater species of Pseudendoclonium Wille (Ulotrichales, 
Ulvophyceae, Chlorophyta). - Arch. Hydrobiol. 82: 79-112.

KomÁreK, J. \& Anagnostidis, K. (1998): Cyanoprokaryota 1. Teil. Chroococcales. In: Ettl, H., Gärtner, G., Heynig, H. \& D. MOLlenhauer (eds): Süsswasserflora von Mitteleuropa, Bd. 19/1. - 548 pp., Gustav Fischer Verlag, Jena, Stuttgart, Lübeck, Ulm.

Komárek, J. \& Anagnostidis, K. (2005): Cyanoprokaryota 2. Teil. Oscillatoriales. - In: BÜDEL, B., Krienitz, L., Gärtner G. \& Schagerl, M. (eds): Süßwasserflora von Mitteleuropa 19/2. 757 pp., Elsevier, Spectrum Akamedischer Verlag, München.

KomÁrek, J. \& FotT, B. (1983): Chlorophyceae (Grünalgen), Ordnung Chlorococcales. - In: Elster, H.J. \& Ohle, W. (eds): Das Phytoplankton des Süsswassers, Die Binnengewässer. Band XVI, 7. Teil, 1. Hälfte. - 1044 pp., Schweizerbart'sche Verlagsbuchhandlung, Stuttgart.

Krumbein, W.E., Braams, J., Grotte, G., Gross, M., Petersen, K., Schostak, V. \& Wahrscheid, T. (1992): Microbial interactions with building stones, with special reference to various cleaning conservation and restoration techniques. - In: Webster R.G.M. (ed.): Stone cleaning and the nature, soiling and decay mechanisms of stone. - pp. 237-238, Avon, The Bata Press.

Krumbein, W.E. \& URzI, C. (1992): Biologically induced decay phenomena of antique marbles - some general considerations. - In: Decrouez, D., Chamay, J. \& Zezza, F. (eds): The conservation of monuments in the Mediterranean Basin. pp. 219-235, 2nd International Symposium, Genéve, November 19.-21, 1991, Genéve.

KapUSTA, M. \& KovÁČIK, L. (2000): Epilithic phycoflora on the selected antropogenic objects in Bratislava (Slovakia). - Bull. Slov. Bot. Spolocn. 22: 15-22.

Lamenti, G., Tiano, P. \& Tomaselli, L. (2000): Biodeterioration of ornamental marble statues in the Boboli Gardens (Florence, Italy). - J Appl. Phycology 12: 427-433.

LokHorst, G.M. (1992): Taxonomic studies in the genus Heterococcus. Cryptogamic Studies Vol. 3. - 246 pp., Gustav Fischer Verlag, Stuttgart, Jena and New York.

LOKHORST, G.M.(1996): Comparative taxonomic studies on the genus Klebsormidium (Charophyceae) in Europe. Cryptogamic Studies Vol. 5. - 132 pp., Gustav Fischer Verlag, Stuttgart, Jena and New York.

Noguerol-Seoane, A. \& Rifón-Lastra, A. (1997): Epilithic phycoflora on monuments. A survey of San Esteban de Ribas de Sil Monastery (Ourense, NW Spain). - Crypt. Algol. 18: 351361.

Ortega-Calvo, J.J., Hernandez-Mariné, M. \& Saiz-
JIMÉNEZ, C. (1991): Biodeterioration of building materials by cyanobacteria and algae. - Int. Biodeter. 28: 165-185.

Ortega-Calvo, J.J., SÁnchez-Castillo, P.M., Hernandez-Mariné, M. \& SAIZ-JimÉnez, C. (1993): Isolation and characterization of epilithic chlorophytes and cyanobacteria from two Spanish cathedrals (Salamanca and Toledo). - Nova Hedwigia 57: 239-253.

Pascher, A. (1939): Heterokonten. - In: Pascher, A. (ed.): Kryptogamenflora von Deutschland, Österreich und der Schweiz, Vol. 11. - 1092 pp., Akademische Verlagsgesellschaft, Stuttgart.

Pentecost, A. (1992): A note on the colonization of limestone rocks by Cyanobacteria. - Arch. Hydrobiol. 124: 167-172.

Rifón-Lastra, A. \& Noguerol-Seoane, A. (2001): Green algae associated with granite walls of monuments in Galicia (NW Spain). - Crypt. Algol. 22: 305-326.

RINDI, F. \& GuIRY, M.D. (2003): Composition and distribution of subaerial algal assemblages in Galway City, western Ireland. - Crypt. Algol. 24: 245-267.

RIPPKA, R. (1988): Isolation and purification of cyanobacteria. - Meth. in Enzym. 167: 3-27.

Rippka, R., Deruelles, J., Waterburz, J.B., Herdman, M.\&STANiER, R.Y.(1979): Generic assignments, strain histories and properties of pure cultures of Cyanobacteria. - J. Gen. Microbiol. 111: 1-61.

Smith, R.L. \& Bold, H.C. (1966): Phycological studies VI. Investigations of the algal genera Eremosphaera and Oocystis. - Univ. Texas Publ. 6612: 1-121.

Uher, B., AboAl, M. \& KovÁčIK, L. (2005): Epilithic and chasmoendolithic phycoflora of monuments and buildings in South-Eastern Spain. - Crypt. Algol. 26: 275-358.

Urzi, C. \& Krumbein, W.E. (1994): Microbiological impacts on the cultural heritage. - In: KRUMBEIN W.E., Brimblecombe P., Cosgrove D.E. \& StANiforth, S. (eds): Durability and change: the science, responsibility, and cost of sustaining cultural heritage. - pp. 107-135, John Willey \& Sons, Chichester, West Sussex.

Wasser, S.P., Lenova, L.I., Stupina, V.V., Tsaren-ko, P.M. \& NAVRotSKAYA, I.L. (1988): Biopovrazhdenyepromishlennykhmaterialovbakteryami, vodorosljami i lishajnikami. - 40 pp., Institut Botaniki im. I.G. Kholodnogo, Kyiv.

(C) Czech Phycological Society

Received March 5, 2008

Accepted November 12, 2008 